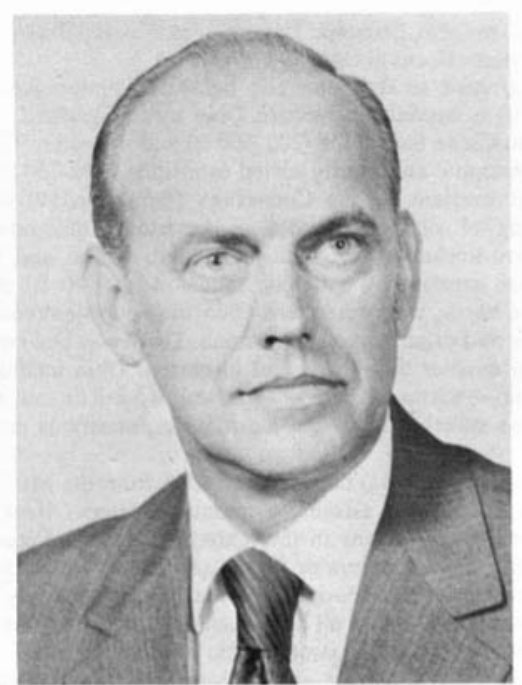

NEW AAPG TREASURER

Fred A. Dix, JR., of Corpus Christi, Texas, has been named treasurer of The American Association of Petroleum Geologists, by James E. WIISON, president.

Dix, 40 , assumed the post left vacant by the air-crash death of H. B. Renfro, 57, of Dallas, who died June 23.

He has been a geologist with Mobil Oil Corp. since 1965, first in Jackson, Miss., and then as associate exploration geologist in Corpus Christi since 1966. It is anticipated he will move to Houston later this year with Mobil.

A member of AAPG since 1957, Dix has been chairman of the Committee on Statistics of Drilling and was also the AAPG representative on several API committees.

He started his career with Standard of California in Salt Lake City and Denver after receiving a B.S. degree and in 1957 an M.S. degree in geology from Rutgers University. He was in the U.S. Air Force from 1953 to 1955, reaching the rank of 1st lieutenant.

Dix is a member of the Corpus Christi Geological Society and the Coastal Bend Geophysical Society.

He was born in Connellsville, $\mathrm{Pa}$., is married and father of 3 children.

\section{EASTERN SECTION,}

FIRST ANNUAL MEETING, MAY 24-27, 1972, COLUMBUS, OHIO

\section{Abstracts of Papers}

BEARDS, R. J., Ontario Department of Mines, Ottawa, Ont., Canada

Silurian Geology of Lake Erie and Associated Gas Production No abstract available.

BULMER, E. G., Ont-Hio Gas and Oil, Inc., Islington, Ont., Canada, and W. E. BULMER, Petroleum Consultant, Chatham, Ont., Canada

Economic Potential of Offinore Oil and Gas Exploration in United States Portion of Lake Erie

The writers have investigated the volumes of crude oil and natural gas reserves which are economically recoverable from the areas underlying the United States portion of Lake Erienot only those reserves which are economically significant at present market prices, but also those which will become profita- ble as the price paid for both crude oil and natural gas in the eastern United States moves upward to levels comparable to those for supplies available from alternative sources.

The availability of present and future markets for oil and gas produced locally, the history of exploration, development, and production in the Lake Erie area, and costs and problems related to offshore operations and production in Lake Erie have been examined. The reserves of crude oil and natural gas recoverable from each potentially productive formation were estimated and allocated by formation to the offshore area occupied by each state which owns mineral rights underlying Lake Erie.

From this study recommendations can be made relevant to the present and/or future need to develop the anticipated offshore oil and gas reserves which underlie Lake Erie and relevant to the need to reevaluate the status of offshore drilling and exploration in the United States portion of the Great Lakes.

CHEN, PING-FAN, and L. D. WOODFORK, West Virginia

Geol. Survey, Morgantown, W. Va.

Lithofacies of Chazy and Chambersburg Groups in Central APpalachians

The post-Beekmantown and pre-Martinsburg rocks of the central Appalachians comprise numerous formations. For the purpose of regional stratigraphic analysis, these rocks can be subdivided into two major units, the Chazy Group at the bottom and the Chambersburg Group above.

The major depocenter during Chazy deposition was located in central Pennsylvania. A medial high divided it into a shallower western part and a more deeply subsiding eastern part. Another broad depocenter existed in central West Virginia. Areas surrounding that depocenter received irregularly varying amounts of sediments. With few exceptions the limestone facies of the Chazy covers the area southeast of the broad depocenter in central West Virginia. Northwestward, dolomite and clastic facies are present, but limestone remains the most important lithology. Areas with higher clastic and dolomite ratios appear to be rather limited.

During the Chambersburg deposition, a depoaxis existed along the Appalachian Valley. Along that axis two separate depocenters existed in western Virginia. Maximum deposition occurred toward the southwest. An axis of thinning (the Adirondack axis) bordered the Appalachian Valley depoaxis on the west along its northern part. However, this positive area died out toward the south, and, therefore, the "Tazewell axis" of thinning appears to have been nonexistent. A large broad depocenter (Allegheny synclinorium) also extended from central West Virginia into eastern Kentucky. Carbonates (almost all limestone) are the most important Chambersburg facies, but facies with higher clastic ratios occur in parts of the Appalachian Valley of Virginia, an isolated area in West Virginia, and a narrow belt in Ohio.

The Trenton Limestone has produced oil in the Rose Hill and Ben Hur fields in Lee County, Virginia. The Trenton-Black River limestone section has produced gas in numerous old fields in west-central New York. Gas shows have been reported from Middle Ordovician carbonates in West Virginia. Additional hydrocarbon reserves should be found in the Middle Ordovician carbonates of the central Appalachians. Areas of local dolomitization and fracture porosity related too structure are considered to be the most promising prospective areas.

\section{CLIFFORD, M. J., Ohio Div. Geol. Survey, Columbus, Ohio}

Role of Silurian Salt in Discordance Between Deep and ShalLow Struçture in Ohio

Interpretations of deep (pre-Cayugan) structure from either shallow structure or seismic information should include an evaluation of the different roles played by the Silurian Cayugan salt beds underlying the central Appalachian basin. Four distinct types of salt involvement are identified in Ohio: thin-skinned thrusting along salt beds (southern Ohio), salt-flowage 